\title{
PRODUCTIVITY GROWTH AND LEVELS IN FRANCE, JAPAN, THE UNITED KINGDOM AND THE UNITED STATES IN THE TWENTIETH CENTURY
}

\author{
Gilbert Cette \\ Yusuf Kocoglu \\ Jacques Mairesse \\ Working Paper 15577 \\ http://www.nber.org/papers/w15577 \\ NATIONAL BUREAU OF ECONOMIC RESEARCH \\ 1050 Massachusetts Avenue \\ Cambridge, MA 02138 \\ December 2009
}

The views expressed herein are those of the author(s) and do not necessarily reflect the views of the National Bureau of Economic Research.

NBER working papers are circulated for discussion and comment purposes. They have not been peerreviewed or been subject to the review by the NBER Board of Directors that accompanies official NBER publications.

(C) 2009 by Gilbert Cette, Yusuf Kocoglu, and Jacques Mairesse. All rights reserved. Short sections of text, not to exceed two paragraphs, may be quoted without explicit permission provided that full credit, including $\odot$ notice, is given to the source. 
Productivity Growth and Levels in France, Japan, the United Kingdom and the United States

in the Twentieth Century

Gilbert Cette, Yusuf Kocoglu, and Jacques Mairesse

NBER Working Paper No. 15577

December 2009

JEL No. E22,J24,N10,O47,O57

\section{ABSTRACT}

This study compares labor and total factor productivity (TFP) in France, Japan, the United Kingdom and the United States in the very long (since 1890) and medium (since 1980) runs. During the past century, the United States has overtaken the United Kingdom and become the leading world economy. During the past 25 years, the four countries have also experienced contrasting advances in productivity, in particular as a result of unequal investment in information and communication technology (ICT).

The past 120 years have been characterized by: (i) rapid economic growth and large productivity gains in all four countries; (ii) a long decline of productivity in the United Kingdom relative to the United States, and to a lesser extent also to France and Japan, a relative decline that was interrupted by the second world war (WW2); (iii) the remarkable catching-up to the United States by France and Japan after WW2, that stopped in the case of Japan during the 1990s.

Capital deepening (at least to the extent this can be measured) accounts for a large share of the variations in performance; increasingly during the past 25 years, this has meant ICT capital deepening. However, the capital contribution to growth varies considerably over time and across the four countries, and it is always less important, except in Japan, than the contribution of the various other factors underlying TFP growth, such as, among others, labor skills, technical and organizational changes and knowledge spillovers.

Most recently (in 2006), before the current financial world crisis, hourly labor productivity levels were slightly higher in France than in the United States, and noticeably lower in the United Kingdom (by roughly 10\%) and even lower in Japan (30\%), while TFP levels are very close in France, the United Kingdom and the United States, but much lower (40\%) in Japan.

Gilbert Cette

Banque de France

1 , rue de la Vrillière

75001 Paris, France

gilbert.cette@banque-france.fr

Yusuf Kocoglu

Léad, Université du Sud Toulon-Var

and Centre d'études de l'emploi

BP 20132

83957 La Garde cedex, France

kocoglu@univ-tln.fr
Jacques Mairesse

INSEE, CREST

15, Boulevard Gabriel PERI

92245 MALAKOFF CEDEX

FRANCE

and NBER

mairesse@ensae.fr 


\section{INTRODUCTION}

Productivity is a key determinant of the wealth of nations. Almost all theoretical and empirical studies that set out to explain the extremely large economic growth and living standard inequalities between countries focus on the differences in productivity levels and growth rates. These studies are numerous and our study, like most others, is based on the traditional "growth accounting" framework (outlined in Box 1). Its contribution is in taking a fresh look at the productivity macroeconomic evidence for France, Japan, the United Kingdom and the United States in the very long run (since 1890) and in the more recent years (since 1980), thus covering a century during which the United States has replaced the United Kingdom as the leading world economic power, and focusing on the past 25 years during which the development of modern information and communication technologies (ICT) has contributed very significantly, albeit unevenly, to productivity growth.

We have tried in this exercise to make the best use of the estimates of aggregate historical data series going back in all four countries to the end of the $19^{\text {th }}$ century for output (GDP), employment, working time and investment in physical capital (see Box 2 on Data Sources). As regards the past 25 years, we relied as much as possible on national accounts data. Many of the estimates on which our comparison is based are subject to a great deal of uncertainty and inaccuracy, not only for the most distant periods but also to a significant extent for the more recent ones. We may nevertheless hopefully consider that the orders of magnitude of these estimates, and the ensuing large differentials in productivity levels and growth rates, are fairly reliable and meaningful. One important reason to be confident is the long tradition of statistics gathering in the four countries. Another is that our comparison is limited to the economies as a whole (and the fact that all four countries had reasonably stable geographic frontiers over our study period). Moreover, given the difficulties of measuring physical capital, as well as unknown differences in measurement methods, we re-estimated capital stocks and services and their contributions to growth for the four countries on the basis of the available investment series, using constant and equal capital stock depreciation rates and shares of services in GDP (see Box 2). Similarly, we 
chose to use the same hedonic price indices (relative to GDP price indices) for computer hardware, software and communication equipment in all four countries, relying on those for the United States, which are arguably those with the largest corrections for improved quality.

In short, we examine productivity growth for the four countries, over the chosen periods

and sub-periods, and using three notions of productivity: labor productivity per employee and per hour, and total factor productivity (TFP), measured as the productivity residual accounting for changes in labor and physical capital input. In Section 2, we compare the long-run trends, and then in Section 3, we focus on the evolution during the past 25 years and on the major role played by the diffusion of ICT during this period.

\section{COMPARING LONG RUN PRODUCTIVITY TRENDS}

In Section 2.1, we first look at the average long run labor productivity and TFP trends over the entire period: 1890-2006 and comment on the 1890 and 2006 corresponding productivity levels. In Section 2.2, we compare these trends and levels for the five following sub-periods: from 1890 to 1913, just before WW1, from 1913 to 1950 (i.e. including the years of the 1929 great depression and those of economic reconstruction and recovery after WW2, in order to smooth out the most significant effects of the conflict on production capacities and economic structures); from 1950 to 1973, just before the first oil shock; from 1973 to 1980, the period between the first and second oil shocks; and from 1980 to 2006, the period we will consider in more detail in Section 3. In Section 2.2, we also carefully compare our productivity estimates to those of several other studies.

\section{1. ...over the entire period}

From 1890 to 2006, the overall growth of labor productivity was remarkable in all four countries. The levels of productivity per employee and per hour increased by a factor of respectively 10 and 20 in France, 25 and 40 in Japan, 5 and 9 in the United Kingdom 
and 7 and 12 in the United States (see Table 1). The large differentials between the growth rates of employee and hourly productivity reflect the huge decline in average annual working time: by roughly 50\% in France (sliding from 3,110 hours in 1890 to 1,540 hours in 2006), by 45\% in the United Kingdom (from 2,990 to 1,670 hours), 40\% in the United States (from 2,850 to 1,710) and 35\% in Japan (from 2,734 to 1,784). Over these (nearly) 120 years, Japan experienced the highest average annual growth: 2.8\% per employee and 3.2\% per hour, and the United Kingdom the lowest: 1.4\% per employee and $1.9 \%$ per hour, while France and the United States were in an intermediate position, with France (2.1\% and 2.7\%) above the United States $(1.8 \%$ and $2.2 \%)$.

In terms of productivity levels, few studies are available on a long period to allow some comparison with our results. Concerning productivity per hour, relative to the United States level, results from Maddison (2007) seem, for Japan and the United Kingdom, very close to ours (see Table 1 and Graphs 1 and 2 for our results, and Appendix Table 1 for the results from Maddison, 2007). ${ }^{1}$

In 1890, the level of labor productivity in the United States, whether per employee or per hour, was roughly four to five times higher than in Japan, 50\% higher than in France, but 25\% lower than in the United Kingdom. ${ }^{2}$ At the time, Japan and France had a much larger proportion of their labor force working in agriculture, as compared with the other two countries. It was still the case in 1970 (see Appendix Table 2). In 2006, the situation is drastically different. The Japanese productivity level, though still the lowest, is about two thirds that of the United States, and the French productivity level is close to that of the

\footnotetext{
${ }^{1}$ Although Maddison (2007) does not give a level comparison for TFP, he provides estimates of capital stock per capita which seem roughly consistent with ours (see Table 6.4, page305). We can thus expect that our estimates of TFP levels of the United Kingdom and Japan relative to the United States are also consistent with his estimates for these countries.

${ }^{2}$ The relative productivity levels for France, Japan and the United Kingdom found in this study differ somewhat from those mentioned in Cette (2004, 2007). These results do not alter the commented stylised facts. The causes of these differences are two-fold. First, the data sources are different: those used in the present study are detailed in Box 1 while in Cette $(2004,2007)$ they are Maddison (1994, 2001 and 2003). Second, in order to ensure the continuity of historical series, we chose to adjust them on the basis of growth rates (as indicated in Box 1).
} 
United States, while the British productivity level is noticeably lower (by about 10\%) than in the United States. ${ }^{3}$

Growth in total factor productivity (TFP) accounts for a major share of hourly labor productivity growth over the past 120 years in the four countries: roughly $50 \%$ to $60 \%$ in France, Japan and in the United Kingdom and $70 \%$ in the United States, while the contribution of capital deepening appears much smaller (see Table 2). Overall, it appears that the factors underlying TFP as computed, such as mainly a better educated and higher skilled labor force, technical and organizational changes, knowledge spillovers, better institutions, make a much greater contribution to observed productivity growth than capital deepening per se.

In 1890, the level of TFP was roughly 100\% higher in the United Kingdom, but 35\% lower in France and 50\% lower in Japan than in the United States. Given that TFP growth was relatively slow in the United Kingdom and fast in France, the level of TFP in both countries was close to that in the United States in 2006. Such remarkable convergence did not occur in Japan: for TFP it stopped at about $60 \%$ of the level of the United States in the early 1970s, and for hourly labor productivity it came to a halt in the early 1990s. To a significant extent, this can probably be attributed to persistent differences in industry composition. In Japan, as evidenced in Table 2, low productivity activities, such as agriculture, construction, trade and catering account for a larger share of the economy than in the other three countries.

\section{1 ...by sub-periods}

Our estimates of employee and hourly productivity growth and of the contributions of capital deepening and TFP are given in Table 2, and shown in the corresponding Graph 3.

\footnotetext{
${ }^{3}$ Bourlès and Cette $(2005,2007)$ have shown that France's strong productivity performance compared to the United States at the end of the period can partly be explained by shorter working hours and a lower employment rate in France and diminishing returns of both working time and employment rate. Adjusting for these effects, the 2006 hourly labor productivity in France appears lower than in the United States by about $5 \%$.
} 
Only a few analyses provide comparable estimations for the four countries over the last century. As expected, our estimates of productivity per employee are very close to those of Maury and Pluyaud (2004), since these authors largely rely on the real GDP and employment data they have gathered and harmonized. The estimates are also consistent with the results presented by Gordon (2003), Cette (2004, 2007) and Van Ark, Frankema and Duteweerd (2004), who measure labor productivity growth over different sub-periods using the real GDP and employment estimates calculated by Maddison (2001). Our estimates of labor productivity and TFP are also consistent with those of Maddison (2007) who makes long-term comparisons between Japan, the United Kingdom and the United States, and considers in particular two of the same sub-periods, 1913-1950 and 1950-1973.

Appendix Tables 3 (France), 4 (Japan, United Kingdom, and United States), and 5 (United States) show selected results from other researchers for comparison. As regards France, the labor productivity and TFP estimates by Dubois (1985), which builds on the major work of Carré, Dubois and Malinvaud (1972), are in very good accordance with ours, although these cover only market activities (and not the whole economy), and in spite of our simplified estimation of physical capital and of its contribution to growth (see Appendix Table 3). For the United Kingdom and Japan, our estimates of labor productivity and TFP growth are very similar to those of Maddison (2007) over both sub-periods 1913-1950 and 1950-1973 (see Appendix Table 4). For the United Kingdom, our estimates are also consistent with those of Crafts (2004a, b and c).

For the United States, our results for hourly productivity are not very different from those of Ferguson and Wascher (2004), although they consider the non-agricultural market sector for slightly different sub-periods (see Appendix Table 5). Our estimates of labor productivity and TFP growth are only roughly consistent with Maddison's: our estimate of TFP growth for the sub-period $1913-1950$ is higher by about $0.7 \%$ per year $(2.3 \%$ instead of $1.6 \%$ ), while our estimate of hourly productivity differs 'only' by $0.3 \%$ (2.8\% instead of $2.5 \%)$. 
If we combine the two sub-periods following the first oil shock (1973-2006), our results confirm the "Big Wave" analysis of productivity in the United States offered by Gordon (1999, 2003). Hourly productivity and TFP in the United States accelerate after 1913, and then slowdown after 1950 and much more after 1973, while the contribution of capital deepening to growth remains almost unchanged. Employee productivity has a different evolution, growing fastest from 1950 to 1973. In France, Japan and the United Kingdom, we also observe such a "Big Wave”. It is, however, shifted forward, with both hourly and employee productivity growing faster during the years 1950-1973 than in the previous years 1913-1950. This appears more pronounced in Japan than in France, and in France than in the United Kingdom. These differences between the three countries and with the United States can be attributed to several factors, among which are the later diffusion of electricity, the slower improvement in the average education and skill level of the workforce (Van Ark, Frankema and Duteweerd, 2004), and greater protectionism (see Gordon, 2003, for a review of the literature). TFP appears to be the main determinant of employee and hourly productivity growth in the four countries, although capital deepening also contributes, especially in Japan since 1950.

Looking more precisely, we see behind these broad similarities substantial differences across the four countries depending on the sub-periods considered.

From 1890 to 1913, France, Japan and the United States experienced similar annual growth rates of productivity per employee (roughly 1.7\%) and per hour (roughly 2\%). Annual productivity growth was lowest in the United Kingdom, mainly on account of a smaller TFP contribution but also lower capital per employee-hour growth. In the four countries, the shares of the contributions of capital deepening and TFP to productivity growth are roughly similar (respectively $1 / 4$ to $1 / 2$ and $1 / 2$ to $3 / 4$ ). Compared to the United States, the level of hourly productivity in France and Japan thus remained unchanged at respectively roughly $45-50 \%$ and $20-25 \%$ of the U.S. level, while that in the United Kingdom dropped from around $125 \%$ to $105 \%$ of that in the U.S. 
From 1913 to 1950, the average yearly growth in employee and hourly productivity was about $1.9 \%$ and $2.8 \%$ in the United States, that is much faster than in France $1.0 \%$ and 1.8\%), Japan (1.3\% and 1.8\%) and especially in the United Kingdom (0.7\% and 1.5\%). Except for Japan, these differences can be attributed to different TFP contributions, since capital deepening increased at about the same rate in all three countries. In Japan, the contribution of capital deepening was very high during this sub-period (roughly $70 \%$ of hourly productivity growth). Consequently, as can be seen on Graph 1, the level of hourly productivity dropped in 1950 moderately for France and Japan (to respectively about 40\% and $20 \%$ of the United States level), and much more for the United Kingdom (to 65\% of the United States level).

From 1950 to 1973, the growth in employee and hourly productivity was particularly strong in Japan (7.5\% and 7.4\% per year respectively) and in France (4.7\% and 5.2\%), and much slower in the United Kingdom (2.5\% and 2.8\%) and in the United States (2.3\% and 2.5\%). The faster productivity growth in Japan and France can be mainly attributed to faster TFP growth, reflecting in part important changes in their economic structure. For example, it is mainly during this period that the share of agriculture in French GDP declined significantly, and became more in line with that in the United Kingdom and the United States. $^{4}$ In 1973, hourly productivity in France and Japan improved markedly to reach a level of about respectively $70 \%$ and $50 \%$ of that of the United States, and France had caught up with the United Kingdom, which had experienced slower productivity growth.

During the short period between the two oil shocks (1973-1980), employee and hourly productivity growth slowed down significantly in the four countries. It was highest in France (2.6\% and 3.4\% per year respectively) and in Japan (2.6\% and 3.2\%), intermediate in the United Kingdom (0.9\% and $2.1 \%)$ and very low in the United States $(0.2 \%$ and $0.7 \%$ ). In all four countries the slowdown in productivity growth is mainly linked to the

\footnotetext{
${ }^{4}$ Card and Freeman (2002) estimated that between 1960 and 1979, the impact on labor productivity of a change in the weight of employment in the agricultural sector amounted to roughly $0.5 \%$ each year in France, against $0.1 \%$ in the United Kingdom and the United States.
} 
slowdown in TFP growth, the contribution of capital deepening being almost unchanged or even higher in Japan compared with the previous sub-period. ${ }^{5}$ By 1980 hourly productivity in France and Japan had reached a level of about respectively $85 \%$ and $50 \%$ of that in the United States, and France had overtaken the United Kingdom (which had a level of 75\%).

During the last sub-period 1980-2006, employee and hourly productivity continued to slowdown in France and Japan but not in the United States where they both strongly accelerated, nor in the United Kingdom, where employee productivity and TFP also recovered and hourly productivity maintaining its pace. Productivity per employee thus increased fastest in the United Kingdom (2.0\% per year), followed by Japan (1.8\%), the United States (1.6\%) and France (1.5\%), while hourly productivity improved most rapidly in Japan (2.4\%), followed by France and the United Kingdom (2.2\%) and the United States (1.6\%). The slowdown in productivity can be attributed to the slowdown in both capital deepening and TFP growth in France, and to capital deepening only in Japan. The acceleration in productivity in the United States and the United Kingdom is also seen in TFP, while the contribution of capital deepening remained about the same in the United States and even declined in the United Kingdom. France continued to experience on average the highest TFP growth, in spite of very significant slowdown (from 1.8\% to $1.3 \%$ per year).

Consequently, the level of hourly productivity relative to that in the United States increased markedly in France to become equal to that in the United States, and to a lesser extent in Japan and in the United Kingdom, reaching roughly 70\% and 90\% of the U. S. level.

\section{LOOKING MORE CLOSELY AT PRODUCTIVITY GROWTH IN THE 1980-2006 PERIOD}

In Section 3.1 we first focus on the changes in productivity growth over the five or ten year sub-periods 1980-1990, 1990-1995, 1995-2000 and 2000-2006, then in Section 3.2 we

\footnotetext{
${ }^{5}$ Cette and Bourlès (2007) have made the case that two thirds of the slowdown in US productivity growth over this sub-period can be accounted for by a rise in the employment rate and a smaller decline in working hours, with strong diminishing returns in both variables.
} 
consider and comment on the specific contribution to growth of the rapid and pervasive diffusion of information and communication technologies (ICT) during these sub-periods.

\subsection{Changes in productivity growth}

Our estimates of employee and hourly productivity growth and the contributions of nonICT and ICT capital deepening and TFP are presented by sub-periods in Table 3, and in the corresponding Graph 4 (in the same format as Table 2 and Graph 3).

During sub-period 1980-1990, employee productivity growth was the highest in Japan with an average rate of $2.7 \%$ per year, followed by France and the United Kingdom with a rate close to $2 \%$, and it was the lowest in the United States with a rate of $1.4 \%$ (still, a much higher average rate than the $0.2 \%$ recorded in the previous sub-period 1973-1980). Hourly productivity growth was much faster in both Japan and France (close to 3\%) than in the United Kingdom (2.0\%) and the United States (1.4\%). The growth differential in hourly productivity between Japan and France on the one hand and the United Kingdom and the United States on the other can be accounted for by a higher TFP contribution $(1.5 \%$ and $1.7 \%$ as against $1.0 \%$ and $0.8 \%$ ), as well as a greater contribution of capital deepening (1.6\% and $1.2 \%$ as against $1.0 \%$ and $0.6 \%)$.

Over the sub-period 1990-1995, productivity growth differed widely across countries. In the United States, it was slightly slower than in the previous sub-period 1980-1990, corresponding to a slower TFP growth. In the United Kingdom, employee and hourly productivity growth increased sharply (by $0.7 \%$ and $0.8 \%$ respectively). A large share of this acceleration is due to a higher contribution of capital deepening. In France, employee and hourly productivity growth slowed considerably, both by about $1.0 \%$. This slowdown reflects almost entirely that in TFP growth (which declined by $1.0 \%$ ), and probably corresponds to a strong cyclical component given the decrease in GDP growth. The stronger TFP growth characteristic of France as compared to the United Kingdom and the United States thus came to an end in the early 1990s. In Japan, employee and hourly productivity growth also slowed down considerably, by $1.8 \%$ and $0.7 \%$ respectively. As in 
France, this slowdown appears to be mostly related to a corresponding slowdown in TFP growth.

The sub-period 1995-2000 is characterized by a significant rise in GDP growth in France, the United Kingdom and the United States (by roughly 1.5\% per year), but not in Japan where GDP growth slowed even further than previously (by 0.5\%). As in the first half of the 1990s, productivity growth has developed differently in the four countries. In the United Kingdom, per hour and hourly productivity growth slowed down by approximately $0.5 \%$ per year, due to a lower contribution of non-ICT capital deepening and of TFP. In France, it remained stable, the acceleration in TFP being offset by a slowdown in non-ICT capital deepening (by $0.6 \%$ ). This slowdown may result partly from the implementation of policies designed to enhance the labor intensity of growth, in particular reducing working time and cutting social contributions targeted at low skilled workers (see Cette, 2004). In the United States, productivity growth gained approximately $1 \%$ due to faster TFP growth. According to Gordon (2005), the fact that productivity accelerates in the United States but slows down in Europe can be attributed to several factors, among which are a predominance of ICT-producing industries, public policies that promote entrepreneurship, and better synergy between public research, private research and the financing of innovation. Finally, in Japan TFP growth remained stable and the slowdown in productivity is entirely due to a slowdown in non-ICT capital deepening.

The last sub-period 2000-2006 is characterized by a slowdown in productivity (about $0.4 \%$ ) in France and the United-Kingdom and a small acceleration in productivity in the other two countries (by $0.2 \%$ ). This is mainly accounted for by a smaller contribution of ICT capital deepening in the United Kingdom, of TFP in France, a higher contribution of capital deepening in the United States and of TFP in Japan.

To conclude, the productivity per employee and per hour graphs show that growth was mostly higher in the United States over the period 1995-2006 than in the other three countries, implying that the catching-up process had slowed or stopped. This result is due to higher growth in both ICT and non-ICT capital intensity and also in TFP (mainly due to 
ICT-producer industries, see below) in the U.S., in comparison with the previous period. Therefore the success of the United States' productivity growth relative to the other three countries over the period 1995-2006 is due to ICT but not to ICT alone.

\subsection{The contribution of ICTs to productivity}

A number of studies (see for example Cette, Mairesse and Kocoglu 2002 and 2005b for a review of the literature) have tried to assess the contribution of ICTs to GDP and productivity growth, many of them relying on macroeconomic evidence and on the growth accounting framework. Most, if not all, of these studies conclude that ICTs have had a positive and significant impact over the past two decades, via two main channels:

- Substitution effects linked to the accumulation of ICT capital (capital deepening), which itself results from the continuous and rapid improvements in the productive performance of ICT investments, leading to a sharp fall in the price of ICT relative to other capital goods and labor. To take the most striking case, in the United States over the 1980-2004 period the price of computer hardware has decreased at an average yearly rate of $15 \%$, while the GDP price deflator increased at an average yearly rate of $3 \%$.

- TFP gains largely driven by rapid technological progress in the different ICTproducing industries.

As stressed in Cette, Mairesse and Kocoglu (2000), the relative importance attached to these two effects in growth accounting analyses depends to a great extent on the methodological choices and practices of statisticians and national accountants in measuring the prices of ICT and using them to construct real ICT investment series from nominal ICT investment. The more the estimation of price changes takes into account the improvements in ICT performance (through substantially upgraded products or new products), by relying in particular on hedonic methods, the larger is the contribution of capital deepening to productivity gains and the lower that of TFP, and conversely. 
In what follows, we first briefly comment on the estimates of the ICT investment ratios to GDP in the four countries, then on the changes in ICT prices. We finally focus on the comparison of our estimates of the ICT capital deepening contribution to productivity growth across the four countries and with other studies.

\section{a) ICT investment ratios to GDP}

Measuring ICT investment in nominal terms already raises a number of difficulties. Putting aside the problem of the availability and reliability of series long enough to estimate capital stocks and services by implementing the (misleadingly called) permanent inventory method, a major difficulty is the breakdown between investment and intermediate consumption of total ICT expenditures, and another one is the measurement of investments in custom software and the purchase of prepackaged software. The solutions adopted by national accountants have differed between countries as well as over time.

For example, following the OECD recommendations on the international harmonization of the methods for measuring software investment, INSEE, the French National Institute for Statistics and Economic Studies, changed its methods for breaking down software expenditures between intermediate consumption and investment on the one hand, and for measuring custom software expenditures on the other. As a result, the amount of software investment in 1999 rose from 11 billion Euros in the previous 1995-based national accounts to 21 billion Euros in the current 2000 base, that is a 90\% increase. In the United Kingdom, Chesson and Chamberlin (2006) have shown that the methodological change in the measurement of software investment, particularly own account software, has led to a rise in the ratio of total software investment to GDP from $0.8 \%$ to $1.8 \%$ in 1999 . These measurement difficulties also affect, but to a lesser extent, the estimation of ICT hardware investment. The estimates presented here are based on the most recent available statistics from all the countries, and therefore different from those in the older comparable studies. ${ }^{6}$

\footnotetext{
${ }^{6}$ For France, these estimates are updated versions of those given in Mairesse, Cette and Kocoglu, 2000, which can be referred to for more details on the assumptions and problems involved in the different steps of the calculations of ICT capital and its contribution to growth.
} 
Looking at Appendix Graph 1, which shows the ICT to GDP investment ratios in the four countries, we observe the following:

- In 1980, ICT investment in the United States accounted for 2\% of GDP against only $1.2 \%$ in France and the United Kingdom and 1.4\% in Japan. By 2005, the share of ICT investment to GDP had increased by a factor of two in the four countries;

- Overall, the ICT investment ratio to GDP has evolved similarly in the four countries. It accelerated from 1980 to 1985 and from 1995 to 2000, and remained stable, or even declined, from 1985 to 1994, and dropped slightly between 2001 and 2005;

- The burst of the Internet bubble in 2000-2001 led to a substantial fall in the ICT investment ratio in the four countries. In the United Kingdom and the United States particularly, the ICT investment ratio fell from 4.9\% to 3.6\% between 2000 and 2005. Such a decline in ICT investment appears to be a correction to overshooting at the end of the 1990s, partly fuelled by the financial market dotcom euphoria and the investment due to the possibility of a Y2K bug.

\section{b) Changes in ICT prices}

As already mentioned, perhaps the major difficulty, and hence the major uncertainty, in

measuring the contribution of ICT capital deepening to growth lies in the measurement of changes in the prices of ICT products, which have had very rapid quality improvements in the recent past. Price statisticians and national accountants are gradually adopting hedonic methods to adjust prices for such quality improvements. However, there are substantial differences in the way in which different countries apply these methods. To avoid that such differences affect our comparison, and considering that ICT products with basically comparable characteristics are produced or imported everywhere in the developed world, we chose to rely only on the United States national accounts price indices for ICT 
products. Precisely, we have assumed that, relative to the overall GDP price index, the quality adjusted prices for the three ICT product categories that can be distinguished in the national accounts (i.e., computer hardware, software and communication equipment) are the same in France, Japan and the United Kingdom as in the United States. This method, proposed by Colecchia and Shreyer (2001), seems realistic enough for developed countries and better than relying on national accounts data for ICT products that are not yet based on harmonized methods for quality adjustment.

Appendix Table 8 gives the overall ICT price average yearly growth rates by sub-period in the four countries calculated by weighting the price growth rates for computer hardware, software and communication equipment. The differences between countries arise from (i) differences in the GDP price growth rates and (ii) differences in the composition of ICT investments in computer hardware, software and communication equipment. Computer hardware experienced the largest price fall relative to other ICT products. ${ }^{7}$ Over the 1980 2005 period, the average annual decline in ICT prices was of the same magnitude in the United Kingdom and the United States (roughly 5\%). In Japan, ICT prices decreased somewhat faster (by 5.7\% per year) due to the slower growth of the GDP price $(0.7 \%$ compared to 3\%) and the larger share of computer hardware. ${ }^{8}$ In France, the price decreased less rapidly (by $4 \%$ per year) because of the smaller share of computer hardware and a faster growth of the GDP price. The 1995-2000 period is that of the most pronounced decease in ICT prices in the four countries, ranging from 6.7\% per year in France to $9.5 \%$ per year in Japan.

\section{c) The contribution of ICT to productivity growth}

The contribution of ICT to labor productivity growth is shown in Table 3 and Graph 4 . The main findings are the following:

\footnotetext{
${ }^{7}$ Between 1980 and 2005, computer hardware prices in the United States decreased at an average annual rate of $15 \%$, compared with roughly $1 \%$ per annum for both software and communication equipment.

${ }^{8}$ On average over the 1980 -2005 period, computer hardware accounted for $25 \%$ of ICT investment in France, against 40\% in the United Kingdom, 28\% in the United States and 45\% in Japan.
} 
- Over the entire 1980-2006 period, the contribution of ICT capital to productivity growth per hour is greater than that of non-ICT capital in the United States but less than that of non-ICT capital in the other three countries;

- The contribution of ICT capital to average annual productivity growth (per employee or per hour) ranges, depending on the period, from 0.3 point to 0.7 point in the United States and the United Kingdom, from 0.3 point to 0.6 point in Japan and finally from 0.2 point to 0.3 point in France. The ICT investment ratio is roughly the same in the United Kingdom and the United States (see Appendix Graph 1), and the contribution of ICT to productivity growth is also the same. This important ICT impact can be attributed to the significantly faster average annual growth rate of the capital stock due to the rapid decrease in the global ICT price index (see Appendix Table 8). Compared to previous studies, the result that the contribution to productivity growth of ICT capital deepening was the same in the United Kingdom and in the United States can be attributed to the improvement in the measures of ICT investment in the United Kingdom from using a more appropriate price index. In France and Japan, the investment ratio is low and the annual growth rate of ICT capital per capita is slightly lower than in the United States;

- In all four countries, the contribution of ICT capital is the largest over the 19952000 period. It amounts to roughly 0.7 point in the United States and the United Kingdom, 0.6 point in Japan and 0.3 point in France. At the same time, the contribution of other equipment and buildings declined considerably in France, Japan and the United Kingdom compared with the previous period (about 1\%). The faster decline in ICT prices over this period (Appendix Table 8) seems to have accelerated the substitution between ICT capital and non-ICT capital;

- Lastly, after 2000, the fall in ICT investment is directly reflected in the contribution of ICT capital to productivity growth. This effect is the less pronounced in France $(-0.1 \%$ and $-0.2 \%$ to $-0.3 \%$ in the other three countries). Except in Japan, this 
period was also marked by an increase in the contribution of non-ICT capital deepening to productivity growth in all countries, particularly in the United States (about $0.4 \%$ ).

Cette and Lopez (2008) analyze in more detail the ICT diffusion gap among major industrialized countries vis à vis the United States during the period 1981-2005. Their results confirm the (positive) impact of the share of the population having completed higher education and the (negative) impact of market rigidities on ICT diffusion. These effects are heightened when ICT diffusion is already substantial. Compared to the United States, the lower ICT diffusion in the United Kingdom is explained by a shortfall in highly educated employees and for France and Japan by both lower shares of highly educated workers and also by higher market rigidities.

On the whole, the results presented here are in keeping with those obtained in the most recent international comparative studies, such as those by Jorgenson and Kuong (2005), the OECD (2003) or Van Ark and Piatkowski (2004), presented in Appendix Table 6. As regards France, they are consistent with our previous assessments (see Cette, Mairesse and Kocoglu, 2005b). For the United Kingdom, they are not directly comparable to the recent assessments by Oulton and Srinivasan (2005) on the market economy; although their profile is similar, the contribution of ICTs is lower than in our estimates. According to these authors, the contribution of ICT capital deepening accounts for $0.7 \%$ of the average annual increase in hourly labor productivity between 1979 and 1990 and for $1.0 \%$ over the 1990-2000 period. As regards the United States, although the scope of the economy covered is different, our results are very close to those of Jorgenson, Ho and Stiroh (2006, 2008), and Oliner, Sichel and Stiroh (2007), presented in Appendix Table 7. As regards Japan, our estimates are close to those of Jorgenson and Kuong (2005) for the 1990s but they show a greater decrease in the contribution of ICT capital-deepening to growth during the period 2000-2006 (see Appendix Table 6).

As mentioned above, national accountants are faced with a number of methodological problems when assessing ICT investment expenditure and establishing the volume-price 
breakdown. However, since national accountants have been following the recommendations of the OECD-Eurostat Software Task Force, the measure of investment in software is more homogenous across countries.

\section{CONCLUSION}

The results of our study, in spite of being highly aggregated and confirming facts for many of them already known, are nevertheless striking. Possibly the most thought provoking findings are the far-reaching changes in the relative economic situation in France, Japan, the United States and the United Kingdom over the long period. While all four countries have experienced very rapid economic growth and extraordinary productivity gains, the past 120 years have also been characterized by the long relative decline of the United Kingdom until WW2, the impressive catching-up of Japan which came to a stop in the 1990s and that by France at least until recently.

At present, total factor productivity is very close in the four countries except Japan, where it is still significantly lower. However, hourly labor productivity is slightly higher in France than in the United States, significantly lower in the United Kingdom, and even lower in Japan. Furthermore, productivity per employee is slightly lower in France than in the United States, much lower in the United Kingdom and even lower in Japan. These differences reflect the more or less contrasting developments during the various periods of the analysis, associated with varying contributions of capital deepening and the downward trend in working hours.

Between 1890 and 2006, a faster drop in working time accounts for roughly 25\% of the differential in the growth of productivity per employee between France and the United States, and just about 5\% of that between the United Kingdom and the United States. Similarly, over the same period, the lower contribution of capital deepening explains 15\% of the differential in the growth of productivity per employee between France and the United States and almost 25\% of that between the United Kingdom and the United States. The other growth factors underlying total factor productivity account for $100 \%$ of France’s 
catching-up with American labor productivity and for $40 \%$ of the decline in British labor productivity compared with the United States. These other growth factors (i.e. working hours and capital deepening "being equal”) would thus account for the almost three-fold increase in French labor productivity compared with the United Kingdom, i.e. an average annual growth differential over 116 years of $1.0 \%$.

It thus appears that the productivity catching-up process differs strongly among countries and periods. The three important questions are then: (i) why do some countries (and not others) benefit at certain periods (and not others) from a productivity catching-up of the highest country level? (ii) What are the determinants of the speed of this catching-up process when it happens? (iii) Why is this catching-up process achieved for some countries but ends before being achieved for others? Important recent literature suggests that these differences can mainly be explained by the education level of the working age population and by institutional aspects, such as rigidities in labor, product and financial markets.

However, the respective contribution of each of these different factors has not been precisely assessed. There is no consensus in the empirical literature on the effect of labor and product markets rigidities on growth. Numerous studies assess very disparate results: either no effect, or a positive or a negative impact (for a survey emphasising this diversity, see Babetskii and Campos, 2007).

In recent analysis, Aghion and Howitt (2006) and Aghion et al. (2009) stress that the education level and rigidities in labor and product markets have different effects depending on whether a country is far from or close to the technological frontier. We know that in the current period market rigidities are, at an aggregate level, the highest in Japan and the lowest in the United States, with France and the United Kingdom being in an intermediate situation. Such higher market rigidities in France, Japan and the United Kingdom than in the United States may have penalized them more in recent years when they are much closer to the United States technological frontier than during the period 1950-1980 when they were much farther from it. This might explain in part why the catching-up process 
with the United States productivity has ended in the last two decades before being completely achieved for France, the United Kingdom and mainly Japan. 


\section{REFERENCES}

Aghion, P., P. Askenazy, R. Bourlès, G. Cette and N. Dromel (2009): "Education, Market Rigidities and Growth”, Economics Letters, n 102, 2008.

Aghion, P. and P. Howitt (2006): “Joseph Schumpeter Lecture - Appropriate Growth Policy : A Unifying Framework”, Journal of the European Economic Association, Vol. 4, Issue 2-3, April-May.

van Ark, B. and M. Piatkowski (2004): "Productivity, Innovation and ICT in Old and New Europe”, Research Memorandum GD-69, Groningen Growth and Development Centre, March.

van Ark, B., E. Frankema and H. Duteweerd (2004): "Productivity and Employment Growth: An Empirical Review of Long and Medium Run Evidence”, Research Memorandum GD-71, Groningen Growth and Development Centre, May.

van Ark, B., M. O’Mahony and M. Timmer (2008): “The Productivity Gap between Europe and the United States: Trends and Causes”, Journal of Economic Perspectives, Vol. 22, N 1, Winter.

Babetskii, I. and N. F. Campos (2007): "Does reform work? An econometric examination of the reform-growth puzzle”, CEPR, Discussion Paper Series, n 6215, April. Bank of Japan (1966): “Hundred Year Statistics of the Japanese Economy”, Statistics Department, Table p. 27.

Bourlès, R. and G. Cette (2005): “A Comparison of Structural Productivity Levels in the Major Industrialised Countries”, OECD Economic Studies, No. 41, 2005/2.

Bourlès, R. and G. Cette (2007): “Trends in 'Structural' Productivity Levels in the Major Industrialized Countries”, Economics Letters, 95.

Cahn, C. and A. Saint-Guilhem (2006): "Potential Output Growth in Several Industrialised Countries: A Comparison”, Mimeo, April.

Card, D. and R. B. Freeman (2002): "What Have Two Decades of British Economic Reform Delivered?”, NBER Working Paper No. 8801, February. 
Carré, J. J., P. Dubois and E. Malinvaud (1972): "La croissance française. Un essai d'analyse économique causale de l'après guerre”, Seuil, Paris.

Cette, G. (2004): “Diagnostic macroéconomique et lecture historique”, in P. Artus et G. Cette (eds.), Productivité et croissance, Rapport du CAE No. 48.

Cette, G. (2007): “Productivité et croissance en Europe et aux États-Unis”, La découverte, Collection Repères.

Cette, G. and J. Lopez (2008): "What Explains the ICT Diffusion Gap Between the Major Industrialized Countries: An Empirical Analysis?”, International Productivity Monitor $\mathrm{n}^{\circ} 17$.

Cette, G., J. Mairesse and Y. Kocoglu (2000): “La mesure de l'investissement en technologies de l'information et de la communication: quelques considérations méthodologiques”, Économie et Statistique, n³39-340, 2000 - 9/10.

Cette, G., J. Mairesse and Y. Kocoglu (2002): "Diffusion of ICTs and Growth of the French Economy over the Long-term, 1980-2000”, International Productivity Monitor, No. 4, Spring.

Cette, G., J. Mairesse and Y. Kocoglu (2005a): "Effets de la diffusion des TIC sur la croissance potentielle et observée”, L'Actualité économique, Revue d'analyse économique, Vol. 81, No. 1-2, March-June 2005.

Cette, G., J. Mairesse and Y. Kocoglu (2005b): “Un siècle de productivité en France”, Banque de France Bulletin No. 139, July.

Chesson, A. and G. Chamberlin (2006): "Survey-based Measures of Software Investment in the UK”, Economic Trends No. 627, February, p. 61-72.

Colecchia, A. and P. Schreyer (2001): "ICT Investment and Economic Growth in the 1990s: Is the United States a Unique Case”, OECD, DSTI/DOC(2001)7, 25 October.

Crafts, N. (2004a): "Steam as a General Purpose Technology: A Growth Accounting Perspective”, The Economic Journal, Vol. 114, April.

Crafts, N. (2004b): "Fifty Years of Economic Growth in Western Europe”, World Economics, Vol. 5, No. 2, April-June.

Crafts, N. (2004c): “The World Economy in the 1990s: A Long Run Perspective”, London School of Economics, Department of Economic History Working Paper No. 87/04, December. 
Dubois, P. (1985): "Rupture de croissance et progrès technique”, Economie et Statistique, No. 181, p. 3-31.

Feinstein, C. (1976): Statistical Tables of National Income, Expenditure and Output of the UK, 1855-1965.

Ferguson, R. W. and W.L. Washer (2004): "Distinguished Lecture on Economics in Government: Lesson from Past Productivity Booms”, Journal of Economic Perspectives, Vol. 18, No. 2, Spring.

Gordon, R. J. (1999): “US Economic Growth since 1970: One Big Wave?”, American Economic Review, Vol. 89, No. 2, p.123-128.

Gordon, R. J. (2003): "Deux siècles de croissance économique: l'Europe à la poursuite des États-Unis”, Revue de l'OFCE, No. 84, Janvier.

Gordon, R. J. (2005): "Pourquoi, pendant que la locomotive de le productivité se mettait en branle aux États-Unis, l'Europe est elle-restée en gare?”, L'Actualité économique, Revue d'analyse économique, Vol. 81, No. 1-2, March-June 2005.

Griliches, Z. (1996): “The Discovery of the Residual: A Historical Note”, Journal of Economic Literature, Vol. XXXIV, p. 1324-1330.

Groningen Growth and Development Database (2007): The June 2007 version of the database may be downloaded at the following address: http://www.ggdc.net.

Jorgenson, D. W., M. S. Ho and K. J Stiroh (2006): "Potential Growth of the US Economy: Will the Productivity Resurgence Continue?”, Business Economy, January.

Jorgenson, D. W., M. S. Ho and K. J. Stiroh (2008): "A Retrospective Look at the U.S. Productivity Growth Resurgence”, Journal of Economic Perspectives, Vol. 22, No 1 , Winter.

Jorgenson, D. W. and V. Kuong (2005): "Information Technology and the World Economy”, Scandinavian Journal of Economics, Vol. 107, issue 4, December 2005.

Jorgenson, D. W. and K. Motohashi (2005): "Information Technology and the Japanese Economy”, Journal of the Japanese and International Economies, Vol. 19, No. 4, December 2005, pp. 460-481.

Kocoglu, Y. (2001): "La productivité du capital productif fixe sur longue période: une analyse empirique sur la France”, Histoire Économie et Société, No. 1, p.65-85. 
Lévy-Leboyer, M. (1978): “Capital investment and Economic Growth in France [18201913]”, in The Cambridge History of Europe, Chapter V, p.231-295.

Maddison, A. (1993): "Standardised Estimates of Fixed Capital Stock: A Six Country Comparison”, Essays on Innovation, Natural Resources and International Economy, from Innovazione e Materie Prime.

Maddison, A. (1994): Dynamic Forces in Capitalist Development, Oxford University Press.

Maddison, A. (2001): “L'économie mondiale: une perspective millénaire”, OECD, Paris. Maddison, A. (2003): “L’économie mondiale: Statistiques historiques”, OECD, Paris.

Maddison, A. (2007): Contours of the World Economy, I-2030 AD, Oxford University Press.

Mairesse, J., G. Cette and Y. Kocoglu (2000): "Les Technologies de l'information et de la communication en France: diffusion et contribution à la croissance”, Économie et Statistique, No. 339-340, 2000 - 9/10.

Maury, T. and B. Pluyaud (2004): "Les ruptures de tendance de la productivité par employé de quelques grands pays industrialisés”, Banque de France Bulletin No. 121, January.

Mitchell, B. (1998): “The Americas, 1750-1993”, International Historical Statistics, $4^{\text {th }}$ Edition, Stockton Press.

Mitchell, B. (1998): “Europe, 1750-1993”, International Historical Statistics, $4^{\text {th }}$ Edition, Stockton Press.

OCDE (2003): “ICT and Economic Growth: Evidence from OECD Countries, Industries and Firms”, OECD 2003, Paris.

Oliner, S., D. Sichel and K. Stiroh (2007): “Explaining a Productive Decade”, Brookings Papers on Economic Activity, 1:2007.

Oulton, N. and S. Srinivasan (2005): "Productivity Growth in UK Industries, 1970-2000:

Structural Change and the Role of ICT”, Bank of England Working Paper No. 259.

Solow, R. (1956): “A Contribution to the Theory of Growth”, Quarterly Journal of Economics, Vol. 70, p. 65-94.

Solow, R. (1957): “Technical Change and Aggregate Production Function”, Review of Economics and Statistics, Vol. 39, p. 312-320. 
Timmer, M. P., G. Ypma and B. van Ark (2003): "IT in the European Union: Driving Productivity Divergence?”, Research Memorandum GD-67, Groningen Growth and Development Centre, October 2003.

Villa, P. (1994): “Un siècle de données macroéconomiques”, Insee Résultats, Série Economie générale, No. 86-87. 


\section{Box 1: The growth accounting approach to estimating the contribution of TFP and capital deepening}

Solow (1956, 1957) was one of the first proponents of the "growth accounting approach" to assess the contributions of the main factors of production to economic growth, in particular capital deepening and "total factor productivity", or TFP. Assuming that the production possibilities may be represented using a production function with a multiplicative TFP term (standing for autonomous technical progress and other unmeasured factors), we can write:

$$
Y=\operatorname{TFP} . F\left(K_{j}, L_{i}\right)
$$

where $Y$ denotes the production output and $K_{j}$ and $L_{i}$ represent respectively the services of the various types capital and labor (or other variable inputs). With a Cobb-Douglas production function, with labor considered as homogeneous (which is the case in the present study), and taking logarithms and first differences (corresponding approximately to growth rates), we obtain the following linear relation:

$$
\Delta y=\Delta t f p+\sum_{j} \alpha_{j} \Delta k_{j}+\beta \Delta l
$$

where $\alpha_{j}$ and $\beta$ are the elasticities of output with respect to the inputs $K_{j}$ and $L$.

Assuming also unit (constant) returns to scale (i.e. $\sum_{j} \alpha_{j}+\beta=1$ ), the growth rate of output can be written as the sum of the growth rate of each input weighted according to its production elasticity and the growth rate of TFP. Growth accounting can also be presented in terms of labor productivity accounting (assuming constant returns to scale), as follows, respectively in log-levels and log-growth rates:

$$
(y-l)=t f p+\sum_{j} \alpha_{j}\left(k_{j}-l\right) \quad \text { and }(\Delta y-\Delta l)=\Delta t f p+\sum_{j} \alpha_{j}\left(\Delta k_{j}-\Delta l\right) .
$$

In order to implement such decomposition, it is necessary to have data on output, labor and capital. In macroeconomic analyses, these data are available in national accounts. The sources used in this study are detailed in Box 2. It is also necessary to measure the output elasticities with respect to the different inputs. In addition to the hypothesis of constant returns to scale, it is generally assumed that production factors are remunerated at their marginal productivity (at least over the medium to long term), which means that it is possible to estimate the factor elasticities on the basis of the share of their remuneration (cost) in total income (or total cost). Given that labor costs (wages and related taxes and social security contributions) represent roughly two thirds of income, we simply took here $\beta=0.7$ and therefore $\sum_{i} \alpha_{i}=0.3$. Note also that we have taken as the measure of capital $K$ used in year $t$ the stock of capital installed at the end of year $(t-1)$.

${ }^{9}$ For a history of growth accounting and TFP ("the residual“), see Griliches (1996) and Maddison (2007). 
TFP is thus measured as a "residual": it is the contribution to labor productivity that is not attributable to all factors not considered explicitly in the growth accounting decomposition. Although such analysis does not provide causal explanations and is mainly descriptive, it can be useful for making comparisons and looking for the sources of differences in productivity levels and growth rates between periods and countries.

In our study, the volume of labor $L$ is written as $L=N^{*} H$ where $N$ is the level of employment and $H$ the average annual working time, and the decomposition of productivity is presented either in terms of productivity per employee or productivity per hour on the basis of the two following relations:

$$
\begin{gathered}
(y-n)=t f p+\sum_{j} \alpha_{j}\left(k_{j}-n\right)+\left(1-\sum_{j} \alpha_{j}\right) h \text { or } \Delta(y-n)=\Delta t f p+\sum_{j} \alpha_{j} \Delta\left(k_{j}-n\right)+\left(1-\sum_{j} \alpha_{j}\right) \Delta h \\
(y-l)=t f p+\sum_{j} \alpha_{j}\left(k_{j}-l\right) \quad \text { or } \quad \Delta(y-l)=\Delta t f p+\sum_{j} \alpha_{j} \Delta\left(k_{j}-l\right)
\end{gathered}
$$

In Table 1 and Graph 2, we present TFP level in France, Japan and the United Kingdom as a \% TFP level. of the United States, where TFP level is computed as: $T F P=\frac{Y / L}{\prod_{j}\left(K_{j} / L\right)^{\alpha j}}$. 


\section{Box 2: Data Sources}

The data sources on which we rely in this study are historical or national accounts series, which we put together to construct indicators over the very long term or, in the case of ICT, over the past few decades. In order to avoid breaks in these indicators, for sources from the more distant periods we calculated them using growth rates applied to the available historical and national accounts series.

In order to compare the levels of variables, we first expressed them in constant domestic currency terms on the basis of the year 2000, and then converted them into 2000 constant dollar terms, using the PPP exchange rates derived implicitly from PPP 2000 constant dollar GDP estimates provided by Maddison (2003).

The most commonly used databases are those of Maury and Pluyaud (2004), Cahn and Saint-Guilhem (2006) and Kocoglu (2001), which we respectively denote by (a), (b) and (c) in what follows.

\section{GDP (gross domestic product)}

- France: National accounts for the period 1959-2006 and Villa (1994)a for the period prior to 1959;

- Japan: National accounts for the period 1994-2006, OECD for the period 1970-1994 and Maddison $(2001,2003)$ for the period prior to 1970;

- United Kingdom: National accounts for the period 1965-2006b, Groningen Growth and Development Centre (GGDC) and Feinstein (1976) for the period prior to 1955a;

- United States: National accounts (BEA) for the period 1929-2006b and Mitchell (1998)a for the period prior to 1929.

\section{Employment (average number of workers)}

- France: National accounts from OECD for the period 1970-2006, GGDC for the period 1959-1970 and Villa (1994)a for the period prior to 1959;

- Japan: OECD for the period 1970-2006, GGDC for the period 1959-1970 and Maddison (2001, 2003) for the period prior to 1959;

- United Kingdom: OECD for the period 1970-2006, GGDC for the period 1959-1980 and Feinstein (1976)a for the period prior to 1959;

- United States: National accounts for the period 1970-2006b, GGDC for the period 1959-1970 and Mitchell (1998)a for the period prior to 1959.

\section{Working time (average number of hours worked per year, per worker)}

- For the four countries: OECD for the period 1970-2006; GGDC for the period 19501969; Maddison (2001) for 1870, 1913 and 1950; linear interpolation for the periods 1890-1913, 1913-1950. 


\section{Investment}

- France: National accounts for the period 1959-2006, Maddison (1993) for the period 1935-1959, Levy-Leboyer (1978)c for the period 1820-1935. The breakdown of total GFCF between equipment and buildings is taken from Villa (1994) for the period 1820-1935;

- Japan: National accounts for the period 1980-2006 and Maddison (1993) for the period prior to 1980 ;

- United Kingdom: National accounts for the period 1965-2006b and Maddison (1993) for the period prior to 1965;

- United States: National accounts for the period 1967-2006b and Maddison (1993) for the period prior to 1967 .

\section{ICT investment}

- $\quad$ France: GGDC (EUKLEMS) for the period 1970-2005;

- $\quad$ Japan: GGDC (EUKLEMS) for the period 1970-2004;

- $\quad$ United Kingdom: GGDC (EUKLEMS) for the period 1970-2005;

- $\quad$ United States: GGDC (EUKLEMS) for the period 1970-2005 and trend from the BEA for the market economy for the period 1959-1969.

\section{Fixed capital}

- Fixed capital series are constructed on the assumption that the annual depreciation rates are: $2.5 \%$ for buildings, $10 \%$ for non-ICT equipment, $15 \%$ for communication equipment and 30\% for computer hardware and software. The coefficients used to take into account WW1 and WW2 damages in France are taken from Villa (1994)c. For Japan, WW2 damages are implicitly taken into account by using the Maddison (1993) growth rate for the period prior to 1946. For this country, the WW2 damage coefficients are those proposed by the Bank of Japan (1966), and the Maddison depreciation assumption (1993) are consistent with ours.

\section{Prices of ICT products}

- The relative ICT price indexes (compared to GDP prices) for France, Japan and the United Kingdom are the same as those taken from the United States national accounts (see Colecchia and Shreyer, 2001, for detailed discussion about this procedure). 


\section{TABLES}

Table 1: Productivity levels and average growth, 1890-2006 -(ppp 2000 dollar)

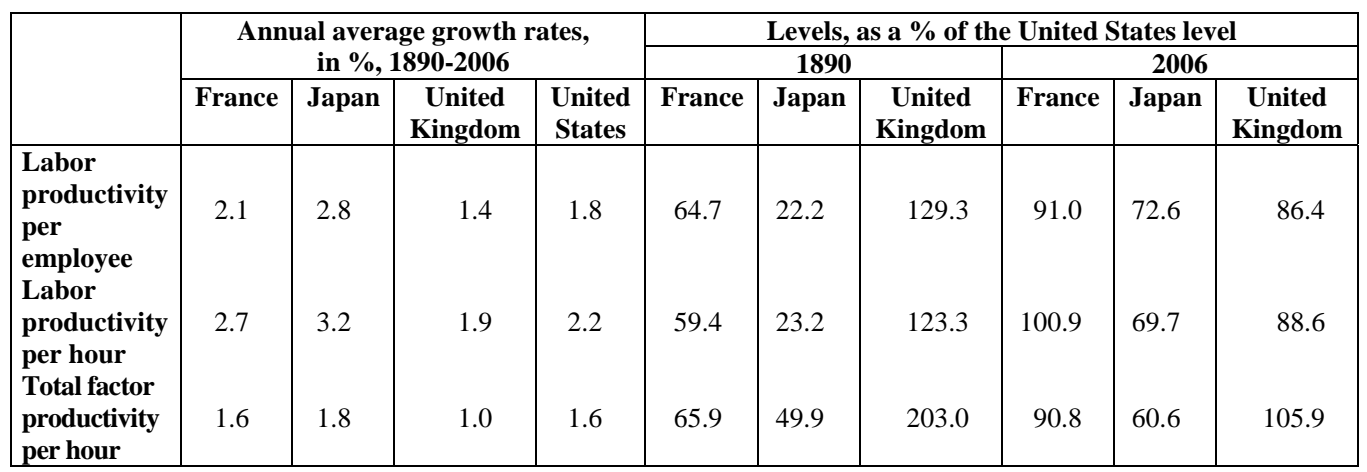

Source: Authors' estimation, see Box 1 for data sources and Box 2 for details on TFP calculations. 
Table 2: Average annual labor productivity growth and contributions (\% per year), in France, Japan, the United Kingdom and the United States

A - France
\begin{tabular}{|l|c|c|c|c|c|}
\hline & $\mathbf{1 8 9 0 - 1 9 1 3}$ & $\mathbf{1 9 1 3 - 1 9 5 0}$ & $\mathbf{1 9 5 0 - 1 9 7 3}$ & $\mathbf{1 9 7 3 - 1 9 8 0}$ & $\mathbf{1 9 8 0 - 2 0 0 6}$ \\
\hline GDP & 1.9 & 0.9 & 5.3 & 2.9 & 2.1 \\
Productivity per employee [a] & 1.6 & 1.0 & 4.7 & 2.6 & 1.5 \\
Productivity per hour [b] & 1.9 & 1.8 & 5.2 & 3.4 & 2.2 \\
\hline Contributions to productivity per & & & & & \\
hour: & & & & & \\
Capital intensity, per hour [c] & 0.5 & 0.3 & 1.2 & 1.6 & 0.9 \\
Total factor productivity [d] & 1.4 & 1.5 & 4.0 & 1.8 & 1.3 \\
\hline
\end{tabular}

B - Japan
\begin{tabular}{|l|c|c|c|c|c|}
\hline & $\mathbf{1 8 9 0 - 1 9 1 3}$ & $\mathbf{1 9 1 3 - 1 9 5 0}$ & $\mathbf{1 9 5 0 - 1 9 7 3}$ & $\mathbf{1 9 7 3 - 1 9 8 0}$ & $\mathbf{1 9 8 0 - 2 0 0 6}$ \\
\hline GDP & 2.5 & 2.2 & 9.3 & 3.4 & 2.3 \\
Productivity per employee [a] & 1.8 & 1.3 & 7.5 & 2.6 & 1.8 \\
Productivity per hour [b] & 2.1 & 1.8 & 7.4 & 3.2 & 2.4 \\
\hline Contributions to productivity per & & & & & \\
hour: & & & & & \\
Capital intensity, per hour [c] & 0.9 & 1.1 & 2.0 & 2.3 & 1.4 \\
Total factor productivity [d] & 1.2 & 0.7 & 5.4 & 0.9 & 1.0 \\
\hline
\end{tabular}

\section{C - United Kingdom}

\begin{tabular}{|l|c|c|c|c|c|}
\hline & $\mathbf{1 8 9 0 - 1 9 1 3}$ & $\mathbf{1 9 1 3 - 1 9 5 0}$ & $\mathbf{1 9 5 0 - 1 9 7 3}$ & $\mathbf{1 9 7 3 - 1 9 8 0}$ & $\mathbf{1 9 8 0 - 2 0 0 6}$ \\
\hline GDP & 1.9 & 1.3 & 2.9 & 1.0 & 2.5 \\
Productivity per employee [a] & 0.9 & 0.7 & 2.5 & 0.9 & 2.0 \\
Productivity per hour [b] & 1.2 & 1.5 & 2.8 & 2.1 & 2.2 \\
\hline Contributions to productivity per & & & & & \\
hour: & & & & & \\
Capital intensity, per hour [c] & 0.3 & 0.5 & 1.6 & 1.6 & 1.1 \\
Total factor productivity [d] & 0.9 & 1.0 & 1.2 & 0.5 & 1.1 \\
\hline
\end{tabular}

\section{D - United States}

\begin{tabular}{|l|c|c|c|c|c|}
\hline & $\mathbf{1 8 9 0 - 1 9 1 3}$ & $\mathbf{1 9 1 3 - 1 9 5 0}$ & $\mathbf{1 9 5 0 - 1 9 7 3}$ & $\mathbf{1 9 7 3 - 1 9 8 0}$ & $\mathbf{1 9 8 0 - 2 0 0 6}$ \\
\hline GDP & 4.1 & 3.2 & 4.0 & 2.5 & 3.1 \\
Productivity per employee [a] & 1.6 & 1.9 & 2.3 & 0.2 & 1.6 \\
Productivity per hour [b] & 2.0 & 2.8 & 2.5 & 0.7 & 1.6 \\
\hline Contributions to productivity per & & & & & \\
hour: & & & & & \\
Capital intensity, per hour [c] & 0.7 & 0.5 & 0.8 & 0.6 & 0.7 \\
Total factor productivity [d] & 1.3 & 2.3 & 1.7 & 0.1 & 0.9 \\
\hline
\end{tabular}

$[\mathrm{b}]=[\mathrm{c}]+[\mathrm{d}]$. Source: Authors' estimation, see Box 1 for data sources and Box 2 for details on TFP calculations. Scope: Economy as a whole 
Table 3: Average annual labor productivity growth and contributions (\% per year), in France, Japan, the United Kingdom and the United States

A - France
\begin{tabular}{|l|c|c|c|c|c|}
\hline & $\mathbf{1 9 8 0 - 2 0 0 6}$ & $\mathbf{1 9 8 0 - 1 9 9 0}$ & $\mathbf{1 9 9 0 - 1 9 9 5}$ & $\mathbf{1 9 9 5 - 2 0 0 0}$ & $\mathbf{2 0 0 0 - 2 0 0 6}$ \\
\hline GDP & 2.1 & 2.4 & 1.2 & 2.8 & 1.7 \\
Productivity per employee [a] & 1.5 & 2.1 & 1.2 & 1.2 & 1.1 \\
Productivity per hour [b] & 2.2 & 2.9 & 1.8 & 1.9 & 1.6 \\
\hline Capital intensity per hour [c] & 0.9 & 1.2 & 1.0 & 0.5 & 0.7 \\
$\quad$ Non-ICT capital intensity per & & & & & \\
$\quad$ hour & 0.6 & 0.9 & 0.8 & 0.2 & 0.4 \\
$\quad$ ICT capital intensity per hour & 0.3 & 0.3 & 0.2 & 0.3 & 0.3 \\
TFP [d] & 1.3 & 1.7 & 0.8 & 1.4 & 0.9 \\
\hline
\end{tabular}

B - Japan
\begin{tabular}{|l|c|c|c|c|c|}
\hline & $\mathbf{1 9 8 0 - 2 0 0 6}$ & $\mathbf{1 9 8 0 - 1 9 9 0}$ & $\mathbf{1 9 9 0 - 1 9 9 5}$ & $\mathbf{1 9 9 5 - 2 0 0 0}$ & $\mathbf{2 0 0 0 - 2 0 0 6}$ \\
\hline GDP & 2.3 & 3.9 & 1.5 & 1.0 & 1.5 \\
Productivity per employee [a] & 1.8 & 2.7 & 0.9 & 1.0 & 1.6 \\
Productivity per hour [b] & 2.4 & 3.1 & 2.4 & 1.7 & 2.0 \\
\hline Capital intensity per hour [c] & 1.4 & 1.6 & 1.9 & 1.5 & 0.8 \\
$\quad$ Non-ICT capital intensity per & & & & & \\
$\quad$ hour & 1.0 & 0.3 & 1.5 & 0.9 & 0.5 \\
$\quad$ ICT capital intensity per hour & 0.4 & 0.3 & 0.4 & 0.6 & 0.3 \\
TFP [d] & 1.0 & 1.5 & 0.5 & 0.2 & 1.2 \\
\hline
\end{tabular}

C - United-Kingdom
\begin{tabular}{|l|c|c|c|c|c|}
\hline & $\mathbf{1 9 8 0 - 2 0 0 6}$ & $\mathbf{1 9 8 0 - 1 9 9 0}$ & $\mathbf{1 9 9 0 - 1 9 9 5}$ & $\mathbf{1 9 9 5 - 2 0 0 0}$ & $\mathbf{2 0 0 0 - 2 0 0 6}$ \\
\hline GDP & 2.5 & 2.6 & 1.7 & 3.2 & 2.5 \\
Productivity per employee [a] & 2.0 & 1.9 & 2.5 & 1.9 & 1.6 \\
Productivity per hour [b] & 2.2 & 2.0 & 2.8 & 2.3 & 2.0 \\
\hline Capital intensity per hour [c] & 1.1 & 1.0 & 1.5 & 1.1 & 0.9 \\
$\quad$ Non-ICT capital intensity per & & & & & \\
$\quad$ hour & 0.6 & 0.6 & 1.1 & 0.4 & 0.5 \\
$\quad$ ICT capital intensity per hour & 0.5 & 0.4 & 0.4 & 0.7 & 0.4 \\
TFP [d] & 1.1 & 1.0 & 1.3 & 1.2 & 1.1 \\
\hline
\end{tabular}

D - United States

\begin{tabular}{|l|c|c|c|c|c|}
\hline & $\mathbf{1 9 8 0 - 2 0 0 6}$ & $\mathbf{1 9 8 0 - 1 9 9 0}$ & $\mathbf{1 9 9 0 - 1 9 9 5}$ & $\mathbf{1 9 9 5 - 2 0 0 0}$ & $\mathbf{2 0 0 0 - 2 0 0 6}$ \\
\hline GDP & 3.1 & 3.3 & 2.5 & 4.1 & 2.4 \\
Productivity per employee [a] & 1.6 & 1.4 & 1.2 & 2.0 & 1.9 \\
Productivity per hour [b] & 1.6 & 1.4 & 1.0 & 2.0 & 2.2 \\
\hline Capital intensity per hour [c] & 0.7 & 0.6 & 0.5 & 0.8 & 1.0 \\
$\quad$ Non-ICT capital intensity per & & & & & \\
$\quad$ hour & 0.3 & 0.3 & 0.2 & 0.1 & 0.6 \\
$\quad$ ICT capital intensity per hour & 0.4 & 0.3 & 0.3 & 0.7 & 0.4 \\
TFP [d] & 0.9 & 0.8 & 0.5 & 1.2 & 1.2 \\
\hline
\end{tabular}

[d] = [b]-[c].Source: Authors' estimation, see Box 1 for data sources and Box 2 for details on TFP calculations. Scope: Economy as a whole 
GRAPHS

Graph 1: Labor productivity per hour, as a \% of the United States level

Scope: Economy as a whole - PPP dollar 2000

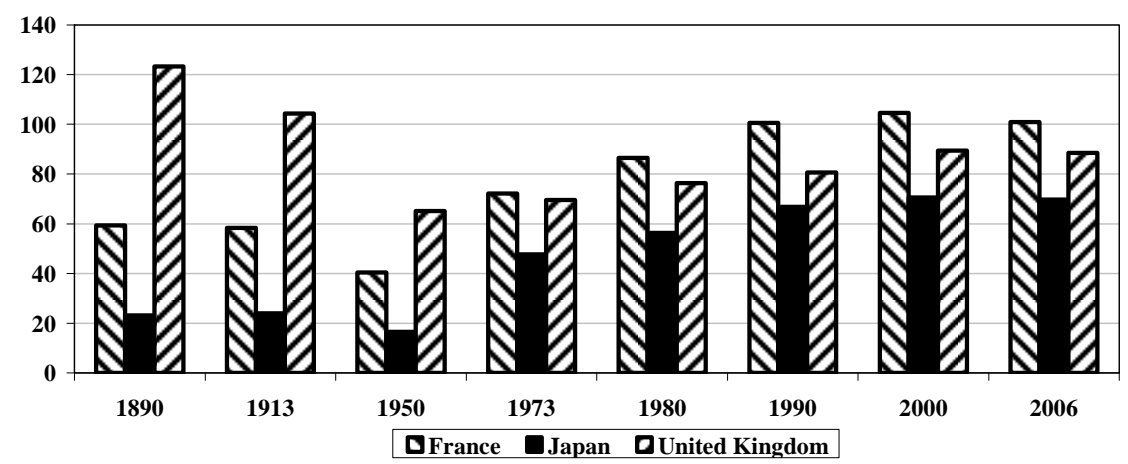

Source: Authors' estimation, see Box 1 for data sources and Box 2 for details on TFP calculations.

Graph 2: Total factor productivity, as a \% of the United States level

Scope: Economy as a whole - PPP dollar 2000

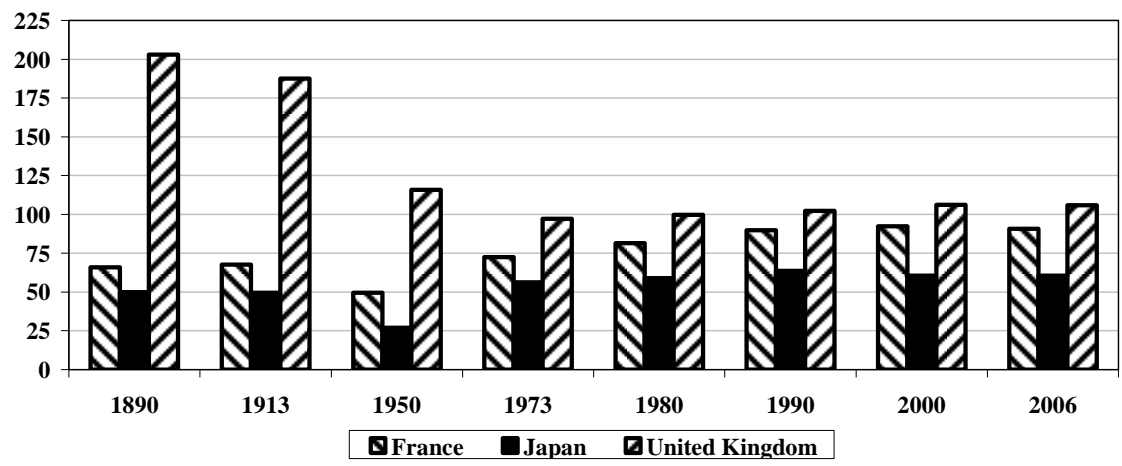

Source: Authors' estimation, see Box 1 for data sources and Box 2 for details on TFP calculations. 
Graph 3: Average annual hourly labor productivity growth (in \%) and contributions in France, Japan, the United Kingdom and the United States - 1890-2006 - In percentage points Scope: Economy as a whole

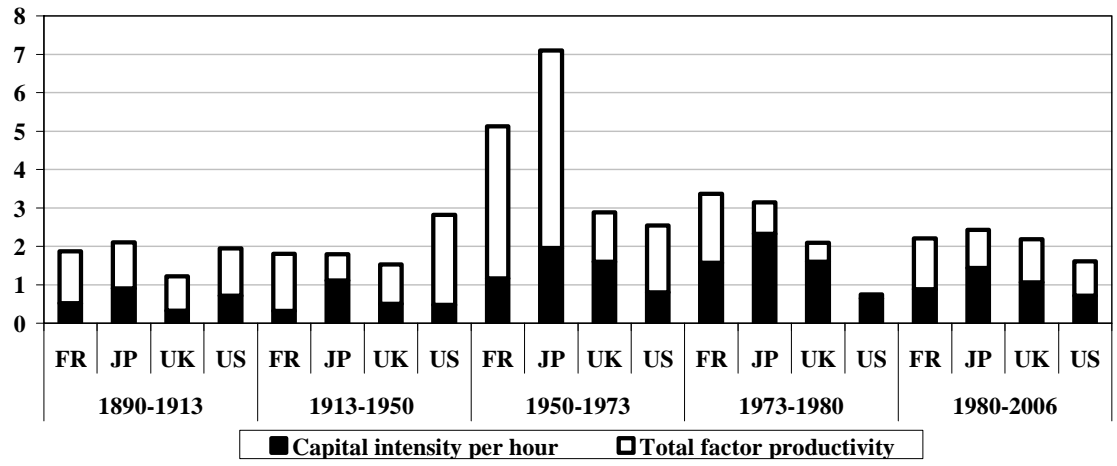

Source: Authors' calculation, see Box 1 for data sources and Box 2 for details on TFP estimations..

Graph 4: Average annual hourly labor productivity growth (in \%) and contributions in France, Japan, the United Kingdom and the United States - 1890-2006 - In percentage points Scope : Economy as a whole

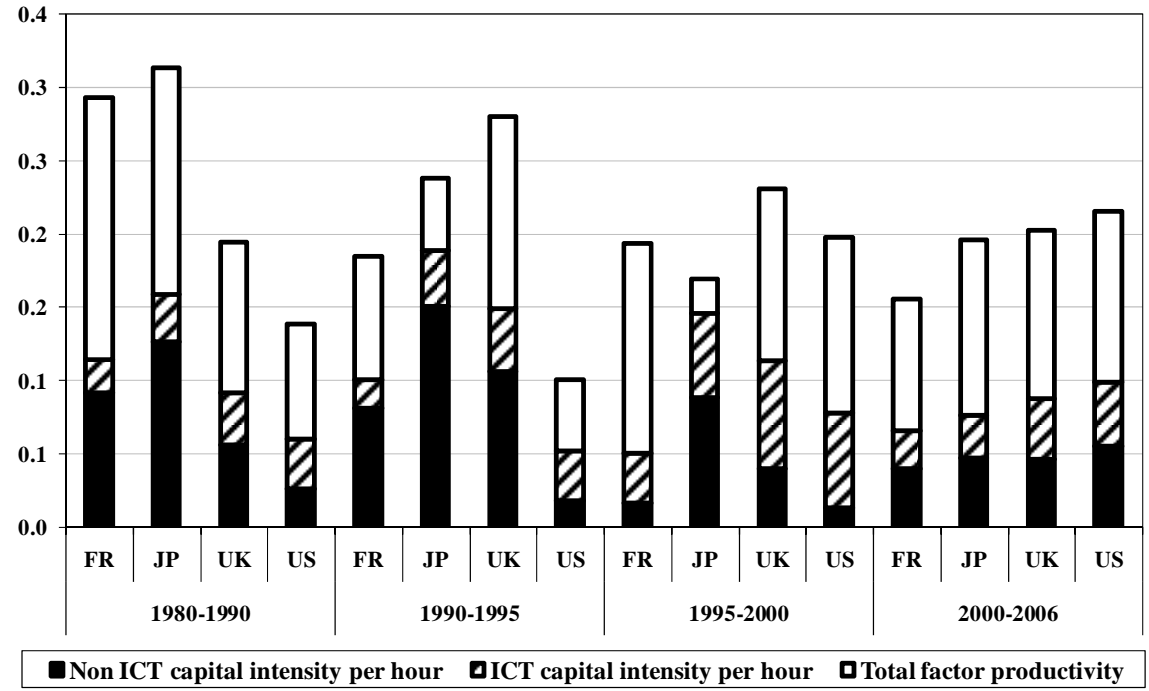

Source: Authors' calculation, see Box 1 for data sources and Box 2 for details on TFP estimations. 


\section{APPENDIX TABLES}

Appendix Table 1: GDP per hour worked, as a \% of the United States level (in ppp 1990\$)

\begin{tabular}{|l|c|c|c|c|c|}
\hline & $\mathbf{1 8 7 0}$ & $\mathbf{1 9 1 3}$ & $\mathbf{1 9 5 0}$ & $\mathbf{1 9 7 3}$ & $\mathbf{2 0 0 3}$ \\
\hline Japan & 20 & 21 & 16 & 49 & 64 \\
United Kingdom & 113 & 84 & 63 & 67 & 79 \\
\hline
\end{tabular}

Source: From Maddison (2007, Table 6.4, p. 305). Scope: Economy as a whole

\begin{tabular}{|c|c|c|c|c|c|c|c|c|}
\hline & \multicolumn{2}{|c|}{ France } & \multicolumn{2}{|c|}{ Japan } & \multicolumn{2}{|c|}{$\begin{array}{c}\text { United } \\
\text { Kingdom }\end{array}$} & \multicolumn{2}{|c|}{ United States } \\
\hline & 1970 & 2004 & 1970 & 2004 & 1970 & 2004 & 1970 & 2004 \\
\hline $\begin{array}{l}\text { Agriculture and } \\
\text { mining }\end{array}$ & 14.3 & 3.7 & 20.2 & 5.4 & 5.2 & 1.5 & 5.2 & 2.8 \\
\hline $\begin{array}{l}\text { Manufacturing, } \\
\text { gas and water }\end{array}$ & 25.8 & 14.4 & 26.5 & 17.7 & 33.0 & 12.3 & 23.2 & 10.9 \\
\hline Construction & 10.2 & 6.3 & 8.1 & 9.0 & 7.2 & 6.8 & 5.0 & 6.0 \\
\hline $\begin{array}{l}\text { Wholesale and } \\
\text { retail trade, } \\
\text { restaurants and } \\
\text { hotels }\end{array}$ & 15.5 & 17.3 & 20.9 & 25.5 & 19.0 & 23.3 & 21.6 & 23.8 \\
\hline $\begin{array}{l}\text { Transport and } \\
\text { storage and } \\
\text { communication }\end{array}$ & 5.6 & 6.2 & 5.6 & 5.8 & 6.7 & 5.9 & 4.6 & 4.2 \\
\hline Other services & 28.7 & 52.0 & 18.8 & 36.6 & 28.9 & 50.2 & 40.5 & 52.3 \\
\hline Total & 100.0 & 100.0 & 100.0 & 100.0 & 100.0 & 100.0 & 100.0 & 100.0 \\
\hline
\end{tabular}

Source: Base EUKLEMS

Appendix Table 3: Breakdown of labor productivity growth in France (\% per year)

\begin{tabular}{|l|c|c|c|c|c|}
\hline & $\mathbf{1 8 9 6 - 1 9 1 3}$ & $\mathbf{1 9 1 3 - 1 9 2 9}$ & $\mathbf{1 9 2 9 - 1 9 5 1}$ & $\mathbf{1 9 5 1 - 1 9 7 3}$ & $\mathbf{1 9 7 3 - 1 9 8 4}$ \\
\hline Productivity per employee & 1.7 & 1.5 & 1.3 & 5.2 & 2.4 \\
Productivity per hour[b] & 2.0 & 2.5 & 1.7 & 5.6 & 3.8 \\
\hline Contributions : & & & & & \\
$\quad$ Capital intensity, per hour [c] & 0.6 & 0.7 & 0.5 & 1.4 & 1.8 \\
$\quad$ Total factor productivity [d] & 1.4 & 1.8 & 1.2 & 4.2 & 2.0 \\
\hline
\end{tabular}

$[\mathrm{b}]=[\mathrm{c}]+[\mathrm{d}]$. Source: Dubois (1985, from Tables 6 and 8, p. 14 and 21). Scope: Business sector. 
Appendix Table 4: Average annual hourly productivity and total factor productivity growth (\% per year)

\begin{tabular}{|l|c|c|c|c|c|c|}
\hline & \multicolumn{3}{|c|}{ Labor productivity } & \multicolumn{3}{c|}{ Total factor productivity } \\
\cline { 2 - 7 } & Japan & $\begin{array}{c}\text { United } \\
\text { Kingdom }\end{array}$ & $\begin{array}{c}\text { United } \\
\text { States }\end{array}$ & Japan & $\begin{array}{c}\text { United } \\
\text { Kingdom }\end{array}$ & $\begin{array}{c}\text { United } \\
\text { States }\end{array}$ \\
\hline $\mathbf{1 8 7 0 - 1 9 1 3}$ & 2.0 & 1.2 & 1.9 & -0.2 & 0.3 & 0.4 \\
$\mathbf{1 9 1 3 - 1 9 5 0}$ & 1.8 & 1.7 & 2.5 & 0.2 & 0.8 & 1.6 \\
$\mathbf{1 9 5 0 - 1 9 7 3}$ & 7.7 & 3.1 & 2.8 & 5.1 & 1.5 & 1.8 \\
$\mathbf{1 9 7 3 - 2 0 0 3}$ & 2.6 & 2.2 & 1.7 & 0.6 & 0.9 & 0.7 \\
\hline
\end{tabular}

Source: Maddison (2007, Table 6.5, p. 306). Scope: Economy as a whole.

Appendix Table 5

Breakdown of United States hourly productivity growth (\% per year)

\begin{tabular}{|l|c|c|c|c|c|c|}
\hline & $\mathbf{1 8 9 0 - 1 9 1 7}$ & $\mathbf{1 9 1 7 - 1 9 2 7}$ & $\begin{array}{c}\mathbf{1 9 2 7 -} \\
\mathbf{1 9 4 8}\end{array}$ & $\mathbf{1 9 4 8 - 1 9 7 3}$ & $\mathbf{1 9 7 3 - 1 9 9 5}$ & $\mathbf{1 9 9 5 - 2 0 0 3}$ \\
\hline Productivity per hour [b] & 1.5 & 3.8 & 1.8 & 2.9 & 1.4 & 3.0 \\
\hline $\begin{array}{l}\text { Contributions : } \\
\begin{array}{l}\text { Capital intensity, per hour } \\
\text { [c] } \\
\text { Total factor productivity [d] }\end{array}\end{array}$ & 0.7 & 1.0 & 0.1 & 1.0 & 1.0 & 1.6 \\
\hline
\end{tabular}

$[\mathrm{b}]=[\mathrm{c}]+[\mathrm{d}]$. Source: Ferguson and Wascher (2004, p. 6). Scope: Non-agricultural market sector.

Appendix Table 6: Average annual ICT contribution to the growth of GDP or labor productivity (\% per year) in France, the United Kingdom, the United States and Japan.

Results of some international comparisons

\begin{tabular}{|c|c|c|c|c|c|c|c|}
\hline & \multicolumn{3}{|c|}{ Jorgenson and Kuong (2005)* } & \multicolumn{2}{|c|}{ OECD (2003)* } & \multirow{2}{*}{\begin{tabular}{|c|}
$\begin{array}{c}\text { Van Ark } \\
\text { and } \\
\text { Piatkowsk } \\
\text { i (2004)** }\end{array}$ \\
$1995-2001$ \\
\end{tabular}} & \multirow{2}{*}{\begin{tabular}{|c|}
$\begin{array}{c}\text { Van Ark, } \\
\text { O’Mahony } \\
\text { and Timmer } \\
(2008)\end{array}$ \\
$1995-2004$ \\
\end{tabular}} \\
\hline & 1989-1995 & 1995-2000 & 2000-2004 & 1990-1995 & 1995-2001 & & \\
\hline France & 0.2 & 0.4 & 0.4 & 0.2 & 0.3 & 0.3 & 0.5 \\
\hline Japan & 0.3 & 0.8 & 0.6 & 0.3 & 0.6 & na & na \\
\hline $\begin{array}{l}\text { United } \\
\text { Kingdom }\end{array}$ & 0.3 & 0.8 & 0.3 & 0.3 & 0.6 & 0.6 & 1.0 \\
\hline United States & 0.5 & 1.0 & 0.6 & 0.5 & 0.9 & 0.7 & 0.8 \\
\hline
\end{tabular}

* Contribution to GDP growth, ** Contribution to the growth of the labor productivity per employee.

Scope: Whole economy 
Appendix Table 7: Average annual labor productivity growth and contributions (\%per year) in the United States

\begin{tabular}{|c|c|c|c|c|c|c|c|c|}
\hline & \multicolumn{3}{|c|}{$\begin{array}{c}\text { Oliner Sichel and Stiroh } \\
(2007)^{*}\end{array}$} & \multicolumn{5}{|c|}{ Jorgenson, Ho and Stiroh (2008)** } \\
\hline & $\begin{array}{l}1973- \\
1995\end{array}$ & $\begin{array}{l}1995- \\
2000\end{array}$ & $\begin{array}{c}2000- \\
2006\end{array}$ & $\begin{array}{c}1959 \\
- \\
2006\end{array}$ & $\begin{array}{c}1959 \\
- \\
1973\end{array}$ & $\begin{array}{l}1973- \\
1995\end{array}$ & $\begin{array}{c}1995 \\
- \\
2000\end{array}$ & $\begin{array}{c}2000 \\
- \\
2006\end{array}$ \\
\hline Productivity per hour & 1.47 & 2.51 & 2.86 & 2.14 & 2.82 & 1.49 & 2.70 & 2.50 \\
\hline Capital intensity per hour & 0.76 & 1.11 & 0.85 & 1.14 & 1.40 & 0.85 & 1.51 & 1.26 \\
\hline $\begin{array}{l}\text { Non-ICT capital intensity } \\
\text { per hour }\end{array}$ & 0.30 & 0.02 & 0.24 & 0.70 & 1.19 & 0.45 & 0.49 & 0.69 \\
\hline $\begin{array}{l}\text { ICT capital intensity per } \\
\text { hour }\end{array}$ & 0.46 & 1.09 & 0.61 & 0.43 & 0.21 & 0.40 & 1.01 & 0.58 \\
\hline TFP & 0.71 & 1.40 & 2.01 & 0.75 & 1.14 & 0.39 & 1.00 & 0.92 \\
\hline
\end{tabular}

Scope: * Non-farm business sector, ** Private economy

Appendix Table 8

Average annual ICT price growth (\% per year) in France, the United Kingdom, the United States and Japan- 1980-2005

\begin{tabular}{|l|c|c|c|c|c|}
\hline & $\mathbf{1 9 8 0 - 2 0 0 5}$ & $\mathbf{1 9 8 0 - 1 9 9 0}$ & $\mathbf{1 9 9 0 - 1 9 9 5}$ & $\mathbf{1 9 9 5 - 2 0 0 0}$ & $\mathbf{2 0 0 0 - 2 0 0 5}$ \\
\hline France & -4.0 & -1.5 & -5.8 & -6.7 & -4.5 \\
Japan & -5.7 & -3.5 & -6.6 & -9.5 & -5.3 \\
United Kingdom & -5.2 & -3.5 & -5.9 & -8.2 & -4.8 \\
United States & -4.8 & -3.5 & -5.4 & -7.4 & -4.3 \\
\hline
\end{tabular}

Sources and estimations: See Box 1. 
Appendix Graph 1

ICT investment -GDP ratio in France, the United Kingdom, the United States and Japan for 1980-2005

In percentage points

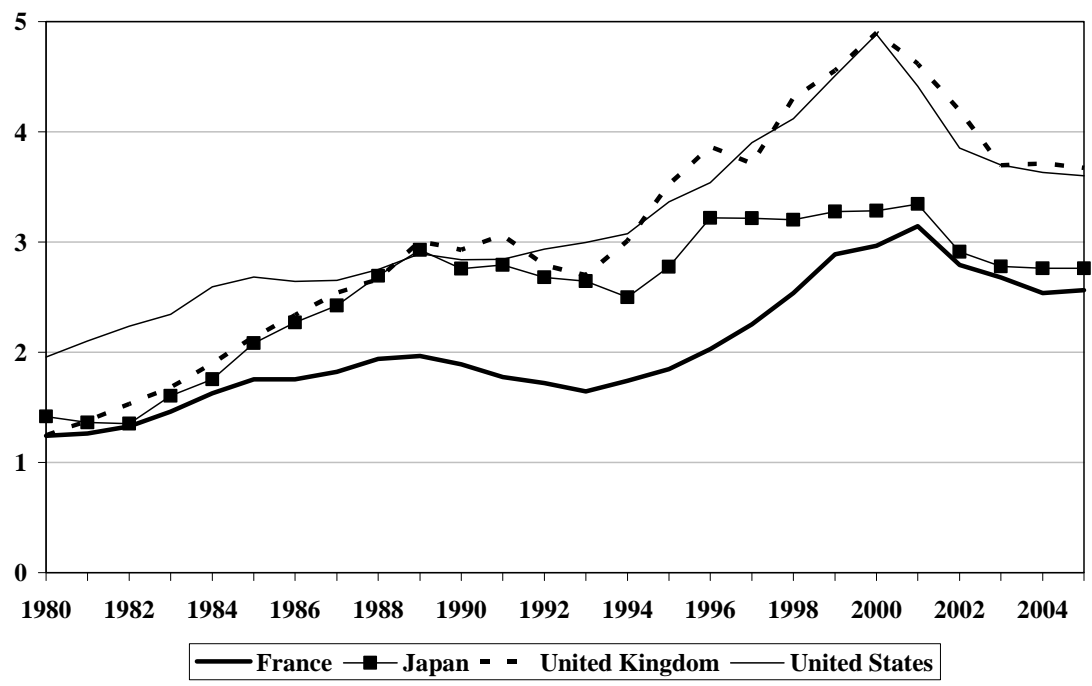

Sources: see Box 1.

Scope: Economy as a whole 